\title{
ACUTE DISORDERS OF BRAIN CIRCULATION AND TYPE 2 DIABETES
}

\author{
${ }^{1}$ Khodjiyeva D.T., ${ }^{1}$ Khaydarova D.K.* ${ }^{2}$ Khaydarov N.K. \\ ${ }^{1}$ Department of Neurology and psychiatry, Bukhara Medical Institute, Bukhara, Uzbekistan; \\ ${ }^{2}$ Tashkent State Dental Institute, Tashkent, Uzbekistan
}

A study of the state of carbohydrate metabolism in patients with acute disorders of cerebral circulation (ADCC) was carried out. It is established that the development of a stroke is often preceded by a period of hyperglycemia. The level of glycosylated hemoglobin affects the clinical course of a stroke, including the restoration of disturbed neurological functions. The debut of diabetes mellitus (DM) can coincide with the development of ADCC.

Keywords: stroke, cerebral circulation disorder, diabetes mellitus, glycosylated hemoglobin.

igh prevalence of cerebrovascular diseases
and severe health consequences determine
their medical and social significance. Stroke is characterized by high lethality and invalidization [1]. In Russia, there are more than 1 million people who have suffered a stroke; while a third of them are working-age people, but only a quarter of them return to work [2]. Diabetes mellitus (DM) is a risk factor for both primary and recurrent stroke. In the conditions of rapid growth of the incidence of type 2 diabetes mellitus (DM 2), recognized by WHO as a non-infectious epidemic, the problem of acute disorders of cerebral circulation (ADCC) in such patients is becoming increasingly important. According to the latest estimates of the International Diabetes Federation, in Russia there are almost 10.9 million patients with DM, of which the vast majority are the patients with DM 2 [3]. The actual prevalence of DM in the most able-bodied part of the population (aged 30 to 50 years) is 3-4 times higher than the one registered for treatment and is $5.5 \%$ of the total population of Russia [4]. With DM 2, the occurrence of cardiovascular diseases sharply increases, often with an unfavorable outcome - up to $75 \%$ of patients die from them [5]. The development of vascular complications in patients with DM is associated mainly with hyperglycemia. As a prospective study of Epic-Norfolk has shown, an increase in glycosylated hemoglobin (HbAlc), an indicator reflecting the average value of glycemia during the last 1-3 months, increases the risk of cardiovascular events [6]. In the same study, it was shown that the risk of stroke increases sharply with the threshold exceeding this value $\geq 7 \%$ [7]. Stroke refers to the main causes of death in patients with DM 2, about $20 \%$ of patients die [8]. Mortality from all cerebrovascular diseases in patients with $\mathrm{DM}$ is higher than in the population, and after the separation of causes of death, an increase in mortality was observed, mainly from ischemic stroke (IS) [9].

Violations of carbohydrate metabolism are determined in $70 \%$ of patients with ADCC, and in some patients DM 2 is first detected in the acute period of stroke, including without a previous increase in glycemia, as evidenced by the level of HbA1c [4]. $\mathrm{DM}$ is detected in $30 \%$ of patients with stroke [9].

Modern achievements of angioneurology made it possible to establish a heterogeneous mechanism for the development of ischemic disorders of cerebral circulation, and sometimes the leading role in the genesis of stroke is attributed to changes in blood biochemistry and hemostasis and fibrinolysis [6], as well as endothelial dysfunction. The accompanying development of IS metabolic syndrome (MS), which includes, in addition to hyperglycemia, also obesity, arterial hypertension, hyperlipidemia, contributes to the initially more pronounced neurologic deficit in the context of significant changes in haemorheological and haemostatic parameters. At the same time, there was also a decrease in the athrombogenic activity of the endothelium and hyperproduction of endothelium-dependent molecules of intercellular adhesion [10,11]. The clinical course of ischemic stroke in patients with DM 2 and MS is characterized by a slower and incomplete recovery of neurological disorders [12]. When providing medical care to patients with IS under unified schemes in patients with DM 2, the worst outcome of the disease is noted [13]. In patients with DM, residual neurological deficit, severe prognosis and mortality are higher compared with patients without DM. Development of metabolic syndrome leads to a decrease in neuroplasticity. The impact on brain plasticity processes is one of the most important scientific areas, since it

*e-mail: dildora_doktor@mail.ru 
will allow to influence the outcome of ADCC, to reduce the level of disability and to improve the results of restorative treatment in neurology [8]. Correction of hyperglycemia refers to the methods of primary and secondary prevention of ADCC [2]. In studying the state of carbohydrate metabolism, the relationship between the level of $\mathrm{HbAlc}$ and the prognosis in patients with ADCC was revealed [10], but there are also data on the absence of dependence of the course and the prognosis of stroke on the duration and degree of decompensation of DM 2 [5].

Moreover, an inverse relationship between the level of HbA1c in patients with DM with the development of atherosclerotic changes in the head main arteries (HMA) and leukoauriosis was revealed [14]. Due to the lack of information and the inconsistency of the above results, the goal of the study was to study the state of carbohydrate metabolism in patients with ADCC.

Materials and methods. The study included 52 patients with ADCC and DM 2 - 27 men (52\%), 25 women $(48 \%)$, mean age $63 \pm 10$ years, on the first day after the development of neurologic symptoms. All patients underwent general investigations and neurological examinations, general clinical and biochemical studies. The diagnosis of ADCC was verified on the basis of the clinical picture and magnetic resonance imaging (MRI) data. During the MRI, the nature of the stroke (ischemic or hemorrhagic) was determined, the magnitude and prevalence of focal brain changes. Duplex scanning was performed to identify and assess the degree of atherosclerosis of the HMA. Based on the main goal of the study, all patients were assessed the level of glycemia on admission, and in the detection of hyperglycemia - in the dynamics. It should be noted that the HbAlc study was conducted for all patients with ADCC (the first day) with glycemia from $6.1 \mathrm{mmol} / 1$ on admission, since it is often difficult to determine whether the patient took food before the development of ADCC. The level of HbAlc, an indicator reflecting the mean values of glycemia over the past few months and having a reliable relationship with the development of diabetic complications, was investigated [4]. At the same time, patients with diabetes mellitus also underwent glycemic control at least 4 times on the first day of the stroke, then, if necessary. The diagnosis of DM was established in accordance with the criteria of the WHO (1999-2006) and the Russian Algorithms of specialized medical care for patients with DM 2013 [1]. Taking into account that hyperglycemia often accompanies ADCC, in patients with glycemic values corresponding to the criteria of $\mathrm{DM}$ in the absence of an increase in $\mathrm{HbAlc}$ of $6.5 \%$, $\mathrm{DM}$ was diagnosed at the end of the acute period of ADCC. All patients included in the study were fully administered therapy, prescribed for acute stroke. Sugar reduction therapy was administered under the control of glycemia. The degree of neurologic impairment in patients with ADCC was determined according to the Scandinavian stroke scale [13] upon admission and on the 21st day from the moment of development of ADCC; The severity of functional disorders was also evaluated according to the modified Rankin scale [6]. Assessment of the clinical status of patients during the acute period of the disease (21 days) was determined by the dynamics of the degree of neurological deficiency as significant, moderate and insignificant. Significant improvement in the condition of patients was noted with a regression of neurological symptoms according to the Scandinavian scale by 10 or more points, and also with a positive dynamics of laboratory indicators; moderate improvement - with a decrease in the neurological deficit of less than 10 points from the baseline and improvement of some laboratory indicators; a slight improvement in the absence or minimal change in neurologic symptoms (by 1-2 points) against the background of consistently poor laboratory indicators. The statistical analysis was carried out using the MS Excel program (Microsoft), and the mathematical processing using the "STATISTICA 8.0" software package. Differences were considered statistically significant at $\mathrm{p}<0.05$.

Results. In the group of included in the study, ischemic stroke was diagnosed in $90 \%$ of cases, hemorrhagic stroke - in $10 \%$. In the majority of patients, atherosclerosis of HMA was detected in $89 \%$ of cases, with hemodynamically significant stenosis $(\geq 60 \%)$ found in $37 \%$ of patients. In neurological imaging, in a prevalent number of observations $(81 \%)$, one focus of brain damage was detected, two or more - in 19\% of patients. Small deep heart attacks occurred in $46 \%$ of patients, medium - in $29 \%$, large - in $21 \%$, and extensive infarcts were detected in $4 \%$ of patients. Atherothrombotic subtype was diagnosed in the 
majority of patients with IS (62\%), hemodynamic - in $2 \%$, cardiogenic - in $26 \%$, lacunar stroke - in $10 \%$ of cases. The level of glycemia at admission on average in the group was $9.3 \pm 2.9 \mathrm{mmol} / \mathrm{l}$, with glycemia 6.5 $\mathrm{mmol} / \mathrm{l}$ and less detected in $7(14 \%)$ patients, ranging from 6.5 to $7,5 \mathrm{mmol} / \mathrm{l}$ in $9(17 \%)$ patients, and more than $7.5 \mathrm{mmol} / \mathrm{l}$ in $36(69 \%)$ patients.

DM 2 was first detected in $29(55.8 \%)$ patients with a glycemic level at the intake of $9.4 \pm 3.4$ $\mathrm{mmol} / \mathrm{l}$. Previously diagnosed with DM 2 lasting less than 5 years was observed in $12(23 \%)$ patients, for a period of 5 to 10 years - in $9(17 \%)$ patients, more than 10 years - in 2 patients $(3.9 \%)$. The determination of the level of HbAlc revealed increased values and averaged $7.8 \pm 2.0 \%$ in the group. The level of HbAlc was less than $6.5 \%$ in $12(22 \%)$ patients, from 6.5 to $6.9 \%$ in $11(20 \%)$, from 7.0 to $7.9 \%$ in $13(24 \%)$, from $8 \%$ and above - in $19(34 \%)$ patients. In $15.4 \%$ of patients, newly diagnosed DM was diagnosed without an increase in HbAlc. Thus, an increase in the level of $\mathrm{HbA} 1 \mathrm{c} \geq 7 \%$ was detected in $58 \%$ of patients, which confirms the previous development of ADCC hyperglycemia.

To determine the degree of influence of prolonged hyperglycemia on the course of a stroke, a correlation analysis of the dependence of the neurological deficit and the parameters of glycosylated hemoglobin was carried out. An inverse correlation was observed between the level of HbAlc and dynamics to 21 days on the Scandinavian scale (Spearman correlation coefficient $r=-0.30, p=0.04$ ). When considering the dynamics of neurologic disturbances with ischemic stroke (IS) during the acute period, marked regression in the neurological status was noted at the level of $\mathrm{HbAlc}$, corresponding to the target values $(<0.05)$.

A significant increase in the overall structure of the incidence of DM, a high risk of cardiovascular complications in, makes the problem of studying

\section{ЛИТЕРАТУРА - REFERENCES - ӘDӘВIYYAT}

1. American Diabetes Association. Standards of Medical Care in Diabetes - 2014. Diabetes Care. 2014; 37: 14-80.

2. Backman J.A., Creager M.A., Libby P. et al. Diabetes and atherosclerosis. Epidemiology, pathophysiology and management. JAMA 2002; 287: 2570-2581.

3. Banerjee C., Moon Y.P, Paik M.C. et al. Duration of diabetes and risk of ischemic stroke: The Northern Manhattan Study. Stroke. 2012; 43 (5): 1212-1217.

4. Heo S.H., Lee S.H., Kim B.J. et al. Does glycated hemo- their interrelation relevant not only because of medical, but also general demographic indicators (reduction and disability with subsequent disability, the risk of death in young and, in particular, reproductive age, as well as impaired fertility, the risk of congenital anomalies of the fetus) [15]. The key factor in the development of such complications is chronic hyperglycemia. The high frequency of association of ADCC and hyperglycemia is the subject of discussion of the leading pathogenetic links of this comorbidity. When considering the question of detectability DM 2 in the ADCC, we have the same frequency - both in women and men. This corresponds to the results of a meta-analysis showing an increase in the risk of stroke in women with diabetes (25), since in the general population, stroke develops more often in men. One of the main stages of realization of a stroke and, accordingly, possible influence on its course, is the violation of carbohydrate metabolism. The population of patients with DM 2 is not homogeneous, the indices of carbohydrate metabolism in different individuals vary from maximally close to normal values and to severe chronic hyperglycemia. The risk of stroke depends on the quality of correction of glycemic disorders. The UKPDS study found that a $1 \%$ reduction in $\mathrm{HbA} 1 \mathrm{c}$ could reduce the risk of stroke by $12 \%$.

Conclusion. The level of $\mathrm{HbAlc}$ may be one of the most important diagnostic and prognostic criteria for the course and outcome of ADCC in patients with impaired carbohydrate metabolism. Such an active approach to detecting violations of carbohydrate metabolism will ensure timely diagnosis of diabetes and assess the prognosis of the disease. The appointment of adequate pathogenetic and personalized therapy, including violations of carbohydrate metabolism, in an acute period of stroke can improve the outcome of the disease and the life expectancy of patients with this combined pathology.

globin have clinical significance in ischemic stroke patients? Clin Neurol Neurosurg. 2010 Feb; 112 (2): 98-102.

5. Huisa B.N, Roy G, Kawano J, Schrader R. Glycosylated hemoglobin for diagnosis of prediabetes in acute ischemic stroke patients. Stroke Cerebrovasc Dis. 2013 Nov; 22 (8): 564-567.

6. International Diabetes Federation, 2013.http://www.idf.org/ diabetesatlas по сост. на 27.02. 2014.

7. Kamouchi M., Matsuki T., Hata J. et al. Prestroke Glycemic Control Is Associated With the Functional Outcome in Acute 
Ischemic Stroke. Stroke.2011; 42: 2788-2794.

8. Khaw K., Wareham N. Glycated hemoglobin as a marker of cardiovascular risk. Curr Opin Lipidol. 2006; 17 (6): 637-643. 9. Laing S.P., Swerdlow A.J., Carpenter L.M. et al. Mortality from cerebrovascular disease in a cohort of 23000 patients with insulin-treated diabetes. Stroke. 2003; Feb; 34 (2): 418-421.

10. Multicenter trial of hemodilution in ischemic stroke-background and study protocol. Scandinavian Stroke Study Group. Stroke. 1985; 16: 885-890.

11. Myint K., Sinha S., Wareham NJ. et al. Glycated hemoglobin and risk of stroke in people without known diabetes in the European Prospective Investigation into Cancer (EPIC)Norfolk prospective population study: a threshold relationship? Stroke. 2007; Feb; 38 (2): 271-275.

12. Peters S.A., Huxley R.R., Woodward M. Diabetes as a risk factor for stroke in women compared with men: a systematic review and metaanalysis of 64 cohorts, including 775385 individuals and 12539 strokes. Lancet. 2014; Mar 6. [Epub ahead of print].

13. Sacks D.B., Arnold M., Bakris G.L. et al. National Academy of Clinical Biochemistry. Position statement executive summary: guidelines and recommendations for laboratory analysis in the diagnosis and management of diabetes mellitus. Diabetes Care 2011;34: 1419-1423.

14. Stöllberger C., Exner I., Finsterer J. et al. Stroke in diabetic and nondiabetic patients: course and prognostic value of admission serum glucose. Ann Med. 2005; 37 (5): 357-364. 15. Stratton I.M., Adler A.I., Neil H.A. et al. Association of glycaemia with macrovascular and microvascular complications of type 2 diabetes (UKPDS 35): prospective observational study. BMJ. 2000.

\title{
XÜLASə
}

\section{BEYIN QAN DÖVRANININ KəSKIN POZULMALARI Və ŞӘKӘRLİ DİABET TİP 2}

\author{
${ }^{1}$ Xodjiyeva D.T., ${ }^{1}$ Xaydarova D.K., ${ }^{1}$ Xaydarov N.K. \\ ${ }^{1}$ Buxara Dövlat Tibb Institutu, nevrologiya va psixiatriya kafedrası, Buxara, Özbəkistan; \\ ${ }^{2}$ Daşkənd Dövlat Stomatoloji İnstitutu, Daşkənd, Özbəkistan
}

Təqdim edilmiş məqalədə beyin qan dövranının kəskin pozulmaları (BQDKP) ilə xəstələrdə karbohidrat mübadiləsinin vəziyyəti tədqiq edilmişdir. Təyin edilmişdir ki, insultun inkişafından əvvəl çox vaxt hiperqlikemiya dövrü müşahidə edilir. Qlikohemoqlabinin səviyyəsi pozulmuş nevroloji funksiyaların bərpası da daxil olmaqla, insultun klinik gedişinə təsir edir. Şəkərli diabetin debütü BQDKP-nın inkişafı ilə üst-üstə düşə bilər.

Açar sözlər: insult, beyin qan dövranının pozulması, şəkərli diabet, qlikohemoqlabin.

\section{РЕЗЮМЕ}

\section{ОСТРЫЕ НАРУШЕНИЯ МОЗГОВОГО КРОВООБРАЩЕНИЯ И САХАРНЫЙ ДИАБЕТ ТИПА 2}

\author{
${ }^{1}$ Ходжиева Д.Т., ${ }^{1}$ Хайдарова Д.К., ${ }^{1}$ Хайдаров Н.К. \\ 'Бухарский Государственный Медицинский Институт, Кафедра неврологии и психиатрии, \\ Бухара, Узбекистан; \\ ${ }^{2}$ Ташкентский Государственный Стоматологический Институт, Ташкент, Узбекистан
}

Проведено исследование состояния углеводного обмена у пациентов с острыми нарушениями мозгового кровообращения (ОНМК). Установлено, что развитию инсульта часто предшествует период гипергликемии. Уровень гликозилированного гемоглобина влияет на клинический ход инсульта, включая восстановление нарушенных неврологических функций. Дебют диабета может совпадать с развитием ОНМК.

Ключевые слова: инсульт, расстройство мозгового кровообращения, сахарный диабет, гликозилированный гемоглобин.

Redaksiyaya daxil olub: 14.06 .2018

Çapa tövsiya olunub: 09.07.2018

Rayçi: t.ü.f.d. Hasanov X.I. 